\title{
Hypertrophic Cardiomyopathy as a Clinical Component of Congenital Cytomegalovirus Infection

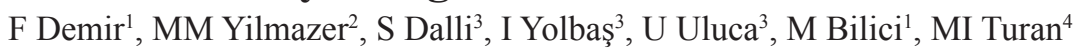

\begin{abstract}
We report hypertrophic cardiomyopathy in a newborn with congenital cytomegalovirus infection. The neonate had distinct signs of congenital cytomegalovirus infection including petechiae, jaundice, intracranial calcifications, cerebral ventriculomegaly and chorioretinitis together with hypertrophic cardiomyopathy. Following determination of anti-cytomegalovirus IgM, viral DNA was also isolated from the plasma of the patient by polymerase chain reaction. Although cytomegalovirus is a relatively frequent cause of myocarditis in childhood, it was rarely reported to be associated with cardiac abnormalities such as structural heart disease, atrioventricular block, or dilated cardiomyopathy. To our knowledge, this is the first case with congenital cytomegalovirus infection and hypertrophic cardiomyopathy.
\end{abstract}

Keywords: Congenital, cytomegalovirus, hypertrophic cardiomyopathy

\section{La miocardiopatía hipertrófica como componente clínico de la infección congénita por citomegalovirus

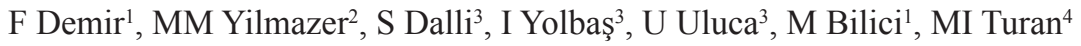

\begin{abstract}
RESUMEN
Reportamos una cardiomiopatía hipertrófica en un recién nacido con infección congénita por citomegalovirus. El neonato exhibía claros signos de infección congénita por citomegalovirus incluyendo petequias, ictericia, calcificaciones intracraneales, ventriculomegalia cerebral, y coriorretinitis con cardiomiopatía hipertrófica. Tras la determinación de IgM anti-citomegalovirus, también se aisló el ADN viral del plasma del paciente mediante reacción en cadena de la polimerasa. Aunque el citomegalovirus es una causa relativamente frecuente de miocarditis en la infancia, raras veces se le ha reportado en asociación con anormalidades cardiacas, tales como la enfermedad cardíaca estructural, el bloqueo auriculoventricular, o la miocardiopatía dilatada. Hasta donde sabemos, éste es el primer caso con infección congénita por citomegalovirus y cardiomiopatía hipertrófica.
\end{abstract}

Palabras claves: Congénita, citomegalovirus, miocardiopatía hipertrófica

West Indian Med J 2016; 65 (2): 409

\section{INTRODUCTION}

Human cytomegalovirus (CMV) is the most common cause of congenital infections, accounting for 0.2 to $2.2 \%$ of all live births (1). Approximately a third of the pregnant women with primary infection and $1.4 \%$ of the women with recurrent infection transmit CMV to their fetuses (2). Only $10 \%$ of the infected fetuses become symptomatic and usual present with anaemia, thrombocytopenia, petechiae/purpura, hepa- tosplenomegaly, jaundice, growth retardation, microcephaly, cerebral calcifications and/or ventriculomegaly, and chorioretinitis in the antenatal or early postnatal period $(2,3)$. Nevertheless, hypertrophic cardiomyopathy (HCM) associated with CMV infection has not been reported so far. In this article, we present the first patient with congenital CMV infection and HCM, to the authors' knowledge.

and Research Hospital, Diyarbakır, Turkey.

From: 'Department of Pediatric Cardiology, Faculty of Medicine, Dicle University, Diyarbakir, Turkey, ${ }^{2}$ Department of Pediatric Cardiology, Behçet Uz Children's Hospital, Izmir, Turkey, ${ }^{3}$ Department of Pediatrics, Faculty of Medicine, Dicle University, Diyarbakır, Turkey and ${ }^{4}$ Department of Pediatric Neurology, Diyarbakır Teaching Diyarbakır Teaching and Research Hospital, Diyarbakır, Turkey. Fax:+904122488523; e-mail: turan78tr@hotmail.com
Correspondence: Dr MI Turan, Department of Pediatric Neurology, 


\section{CASE REPORT}

A female newborn was born after 36 weeks of gestation by emergency Caesarean section due to fetal distress. The neonate was stabilized quickly, but one hour after the delivery, she was noted to have poor sucking and petechial lesions on her abdomen. She was born of a 23-year old woman and was her first pregnancy. Her mother had no prenatal problem identified including viral illnesses. None of the family members had known myocardial disease, arrhythmia, syncope and history of sudden death. On physical examination, the newborn had hypotonia, petechial skin lesions and hepatomegaly. The liver was palpable $4 \mathrm{~cm}$ below the right costal margin at the midclavicular line. She had a body weight of $2800\left(50-75^{\text {th }}\right.$ percentile), a head circumference of $36 \mathrm{~cm}\left(75-90^{\text {th }}\right.$ percentile), and a height of $50 \mathrm{~cm}\left(75-90^{\text {th }}\right.$ percentile $)$. She had thrombocytopenia (90 x 109/L [normal ranges: $\left.\left.84-478 \times 10^{9} / \mathrm{L}\right]\right)$ and increased liver enzymes (alanine aminotransferase: 278 IU/L [normal ranges: 6-50 IU/L], aspartate aminotransferase: 913 IU/L [normal ranges: 35-140 IU/L]). After obtaining blood and urine cultures, ampicillin (50 mg/kg/dose every 12 hours) and gentamicin $(2.5 \mathrm{mg} / \mathrm{kg} /$ dose every 12 hours $)$ were initiated intravenously. As she developed significant and rapidly progressive jaundice (total serum bilirubin: $19.3 \mathrm{mg} / \mathrm{dL}$ [nor$\mathrm{mal}<2 \mathrm{mg} / \mathrm{dL}$ ] and conjugated bilirubin: $11.8 \mathrm{mg} / \mathrm{dL}$ [normal $<0.3 \mathrm{mg} / \mathrm{dL}]$ ) within hours, exchange transfusion was performed. Cranial ultrasonography revealed marked dilatation of the lateral ventricles. Parenteral ganciclovir therapy (6 $\mathrm{mg} / \mathrm{kg} /$ dose every 12 hours) was started on the second day following determination of anti-CMV IgM antibodies in the serum obtained just before transfusion. The cranial computed tomography confirmed the lateral ventricular dilatations and showed periventricular calcifications. Ophthalmological examination revealed bilateral chorioretinitis, characterized by areas of active inflammation and mild necrosis just around the optic discs. A systolic murmur heard over the cardiac apex on day four led us to a cardiac assessment. Electrocardiogram was normal. Echocardiographic examination revealed global thickening of the left ventricular walls together with a moderate sized patent ductus arteriosus [PDA] $(2 \mathrm{~mm})$ and mild mitral insufficiency. Left atrium-to-aortic root ratio was measured as $1.5 / 1$ [normal $<1.4 / 1]$. The thickening of the septal wall was more pronounced. The interventricular septum and the left ventricular posterior wall diastolic thicknesses were measured as 14 and $11 \mathrm{~mm}$, respectively [both normal values $<5.5 \mathrm{~mm}$ ] (Figure).

However, left ventricular outflow tract obstruction or systolic anterior motion of the mitral valve was not detected. Systolic and diastolic functions were found as normal (fractional shortening was $41 \%$, mitral valve E-to-A ratio was 1.9 ). Oral ibuprofen therapy ( $10 \mathrm{mg} / \mathrm{kg} /$ dose every 24 hours) was started for closure of PDA.

The diagnosis of congenital CMV infection was established definitively after detection of CMV DNA by polymerase chain reaction (PCR). Ampicillin and gentamicin were stopped after negative culture results. Patent ductus arteriosus

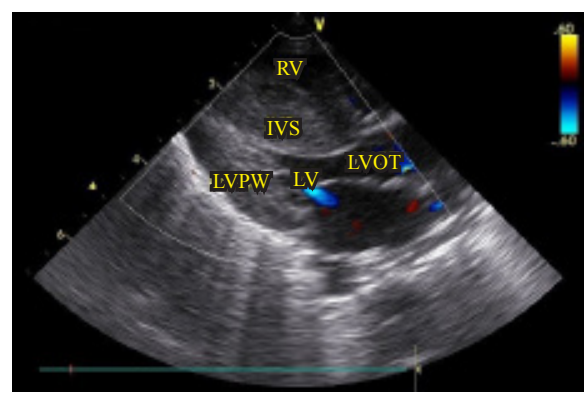

Figure: Parasternal long axis view demonstrating hypertrophic cardiomyopathy. IVS: interventricular septum, LV: left ventricle, LVOT: left ventricular outflow tract, LVPW: left ventricular posterior wall, RV: right ventricle.

closed following three days of ibuprofen therapy. Her hypotonia, poor sucking and petechial lesions disappeared and activity returned to normal at the end of the first week. Hyperbilirubinaemia and liver enzymes improved to near normal values (total bilirubin: $3.3 \mathrm{mg} / \mathrm{dL}$, conjugated bilirubin: 0.9 $\mathrm{mg} / \mathrm{dL}$, alanine aminotransferase: $54 \mathrm{IU} / \mathrm{L}$, aspartate aminotransferase: $62 \mathrm{IU} / \mathrm{L})$. Ganciclovir therapy was terminated two weeks later following disappearence of CMV DNA and she was discharged from the hospital. A ventriculo-peritoneal shunt was performed for hydrocephalus at the fourth postnatal month. Left ventricular septal thickness was $12.9 \mathrm{~mm}$ and posterior wall thickness was $8.8 \mathrm{~mm}$ one year after discharge. At the end of a follow-up of 25 months, left ventricular septal and posterior wall thicknesses were measured to be 11.8 and $7 \mathrm{~mm}$, respectively [both normal values were $<7 \mathrm{~mm}$ for her current weight (13 kilograms)]. Her cardiovascular examination was normal and no other echocardiographic abnormality was determined. Her motor skills were delayed by a few months (not documented with any test).

\section{DISCUSSION}

Congenital CMV infection is generally asymptomatic and it is characterized by multi-organ involvement in $10 \%$ of the infected neonates. The brain, liver, spleen, pancreas, heart, lungs, kidneys and eyes are the most commonly affected organs (3). Thrombocytopenia and petechiae are frequent findings. Liver involvement is characterized by hepatomegaly, conjugated hyperbilirubinaemia and elevated liver transaminase levels. Central nervous system involvement is the predominant cause of adverse outcome such as mental retardation and hearing loss $(2,3)$.

Besides being a potential cause of myocarditis in the paediatric population, CMV is also associated with certain forms of cardiac involvement through its congenital infection. Cytomegalovirus nucleic acids were determined in myocytes of the majority of the cases with fatal myocarditis (4). The histologic features of myocarditis associated with CMV or other infectious agents consist of inflammatory infiltrates and necrosis of myocytes (5). Chronic viral myocardial infections including CMV were accused of causing dilated cardiomyopathy through partially unknown mechanisms. Cell-mediated autoimmune response to viruses or persisting viral particles 
such as RNA and production of some autoantibodies, crossreacting with viral proteins and cardiac myosin, may have roles in the pathogenesis of cardiomyopathy $(6,7)$. Some structural heart diseases associated with congenital CMV infection were also reported. Patent ductus arteriosus, atrial septal defect, ventricular septal defect (VSD), Fallot's tetralogy, complex cyanotic heart diseases, ventricular aneurysm and atrioventricular block were the major abnormalities denoted to be related with such infection $(2,8)$. The frequencies of ventricular septal defect and Fallot's tetralogy were found higher in the $\mathrm{CMV}$-infected population than the general population, though the pathogenetic mechanisms were not determined (2).

Cytomegalovirus is a relatively common cause of myocarditis. Left ventricular hypertrophy was observed, albeit not frequently, in the course of various forms of myocarditis. Although such cases were accompanied by systolic dysfunction and generally reversible, the persistence of cardiac hypertrophy was encountered in a few patients (9). The incidence of symptomatic congenital CMV infection was found as $1 \%$ in a study from our country (10). Acquired and usually reversible causes of ventricular hypertrophy such as gestational diabetes and corticosteroid use were not present in our CMV-infected patient. The incidence of infantile HCM was reported as 30/1 000000 cases (11). The cases with HCM often have several gene mutations, while sporadic, nonfamilial cases are occasionally determined and the cause of those remains unknown. There was no respiratory distress, persistent hypotonia, history of familial HCM or parental consanguinity and the blood creatine kinase level was normal. Therefore, Pompe disease was excluded. However, a further investigation including myocardial biopsy or mutation analysis was not performed. Although it cannot be proven that the ventricular hypertrophy in our case is not a coincidental finding, we think that HCM might have resulted from CMV-associated microRNA regulation or myocardin stimulation, as well as it might be a sequelae of CMV myocarditis through unknown pathogenetic mechanisms.
As congenital CMV infection may be associated with cardiomyopathy and congenital heart disease in some instances, fetal or transthoracic echocardiography may be of value, if available, in the cases with suspicion of such infection. To the best of our knowledge, the case presented here is the first $\mathrm{CMV}$-infected patient diagnosed with HCM in the literature.

\section{REFERENCES}

1. Bissinger AL, Sinzger C, Kaiserling E, Jahn G. Human cytomegalovirus as a direct pathogen: correlation of multiorgan involvement and cell distribution with clinical and pathological findings in a case of congenital inclusion disease. J Med Virol 2002; 67: 200-6.

2. Malm G, Engman ML. Congenital cytomegalovirus infections. Semin Fetal Neonatal Med 2007; 12: 154-9.

3. Gabrielli L, Bonasoni MP, Lazzarotto T, Lega S, Santini D, Foschini MP et al. Histological findings in foetuses congenitally infected by cytomegmegalovirus. J Clin Virol 2009; 46 (Suppl 4:) 16-21.

4. Kearney MT, Cotton JM, Richardson PJ, Shah AM. Viral myocarditis and dilated cardiomyopathy: mechanisms, manifestations, and management. Postgrad Med J 2001; 77: 4-10.

5. Sanchez GR, Neches WH, Jaffe R. Myocardial aneurysm in association with disseminated cytomegalovirus infection. Pediatr Cardiol 1982; 2: 63-5.

6. Enders G, Bader U, Lindemann L, Schalasta G, Daiminger A. Prenatal diagnosis of congenital cytomegalovirus infection in 189 pregnancies with known outcome. Prenat Diagn 2001; 21: 362-77.

7. Mian Said ASh, Stulova MA. Hypertrophic cardiomyopathy and viral, idiopathic myopericarditis. Klin Med (Mosk) 2000; 78: 15-21 (abstract).

8. Sayed D, Hong C, Chen IY, Lypowy J, Abdellatif M. MicroRNAs play an esssential role in the development of cardiac hypertrophy. Circ Res 2007; 100: 416-24.

9. Zhou J, Liao XH, Wu C, Li J, Xiao R, Cheng C et al. The synergistic effects of cytomegalovirus IE2 and myocardin on cardiomyocyte hypertrophy. FEBS Lett 2011; 585: 1082-8.

10. Satilmiş A, Güra A, Ongun H, Mendilcioğlu I, Colak D, Oygür N. CMV seroconversion in pregnants and the incidence of congenital CMV infection. Turk J Pediatr 2007; 49: 30-6.

11. Colan SD, Lipshultz SE, Lowe AM, Sleeper LA, Messere J, Cox GF et al. Epidemiology and cause-specific outcome of hypertrophic cardiomyopathy in children: findings from the Pediatric Cardiomyopathy Registry. Circulation 2007; 115: 773-81 